\title{
Bioremoval of lead and iron from sewage water by mangrove-derived Hypocrea lixii
}

\author{
K. Saravanakumar $\cdot$ K. Kathiresan
}

Received: 19 August 2013/Revised: 21 April 2014/ Accepted: 27 October 2014/Published online: 6 November 2014

(C) Islamic Azad University (IAU) 2014

\begin{abstract}
This work focused on the bioremoval of heavy metals by mangrove-derived Trichoderma biomass in the artificial sewage water. Of the 12 isolates tested, Hypocrea lixii TSK8 (JQ809340) was found to be a potent strain in removal of lead and iron. The bioremoval was enhanced through adsorption kinetics and process optimization using statistical model of the response surface methodology. The magnitude of Langmuir constant was $0.64 \mathrm{~L} \mathrm{mg}^{-1}$ and $0.42 \mathrm{~L} \mathrm{mg}^{-1}$ for lead and iron, respectively. Adsorption capacity was determined as $49.2 \mathrm{mg} \mathrm{g}^{-1}$ and $51.3 \mathrm{mg} \mathrm{g}^{-1}$ for lead and iron, respectively. The optimized conditions for maximum removal of lead and iron were standardized. The biosorption of metals was also confirmed by scanning electron microscopic and X-ray energy-dispersive spectrometer analyses. The results revealed that dried biomass of the H. lixii TSK8 was a potent biosorbent for efficient bioremoval of lead and iron.
\end{abstract}

Keywords Mangroves - Trichoderma $\cdot$ Hypocrea lixii . Bioadsorption · Response surface methodology

\section{Introduction}

Industrial discharges increasingly cause metal pollution. When the pollutants get accumulated, they damage the

Electronic supplementary material The online version of this article (doi:10.1007/s13762-014-0703-z) contains supplementary material, which is available to authorized users.

K. Saravanakumar $(\square) \cdot$ K. Kathiresan

Faculty of Marine Sciences, Centre of Advanced Study in

Marine Biology, Annamalai University, Parangipettai 608502,

Tamil Nadu, India

e-mail: saravana732@gmail.com biological species of terrestrial and marine environments (Travieso et al. 2002). The metal accumulations also induce environmental changes through their conversion and productions of the toxic chemicals, which may induce cancers in human and animals (Canizares-Villanueva and Travieso 1991; Tastan et al. 2010). Lead (Pb) gets accumulated naturally at the level from 5 to $25 \mathrm{mg} \mathrm{kg}^{-1}$ in soils and $<0.45-14 \mathrm{mg} \mathrm{L}^{-1}$ in groundwater (Smedley et al. 2003). The $\mathrm{Pb}$ accumulation has increased due to the human activities such as manufacturing of battery, printing, painting, dying, textile, photographic materials, ceramic and glass industries (Yetilmezsoy et al. 2009). $\mathrm{Pb}$ has carcinogenic effect in significantly damaging the cells and causing cancers (Silbergeld et al. 2000; Srivastava et al. 2004). Natural iron is essential to human diet although the higher iron dosage of $350-500 \mu \mathrm{g} \mathrm{dL}^{-1}$ in blood can damage the internal organs, brain, liver cells and poisoning to human (Allen 2002). Therefore, it is highly essential to remove $\mathrm{Pb}$ and iron from the effluent before discharging it into environment.

Currently researchers developed many types of the metal removal techniques such as membrane separation (Mavrov et al. 2006), ion exchange (Cavaco et al. 2007), lime precipitation (Zhang et al. 2007), metal hydroxide precipitation (Ayyappan et al. 2003), electrolytic methods (Kurt et al. 2007) and adsorption (Dean et al. 1972). However, most of these methods are not cost-effective (Dae and Young 2005; Brasil et al. 2006), but in the case of the adsorption technique, many types of cheapest adsorbents such as wood materials, agricultural waste materials and dried microbial biomass have been used. Of the adsorbents, the dried microbial biomass has a high efficiency on removal of the toxic metals from the effluents due to their binding ability (Xiao et al. 2010). In use of microbial adsorbent, the major challenge is in selection of a 
potential microbial biomass with significant biomass production for efficient removal of the metals (Deng et al. 2011). The use of filamentous fungi may provide some advantages over bacterial adsorbent in the case higher biomass and enzyme production (Annibale et al. 2006). Many fungi, such as Mucor rouxii, Trichoderma, Aspergillus, Paecilomyces lilacinus and the arbuscular mycorrhizal fungi, are known to have potential for bioremediation in metal-contaminated soils (Lo et al. 1999; Akhtara et al. 2007; Adams et al. 2007; Lebeau et al. 2008; Tsekova et al. 2010; Sharma and Adholeya 2011). Hypocrea lixii isolated the water collected from a pond of copper waste is proved to be an economically viable source for bioremediation of wastewater and industrial-scale production of copper NPs (Marcia et al. 2013). Pleurotus ostreatus is a potential microorganism in liquid laboratory chemical waste treatment especially biosorption of $\mathrm{Cr}(\mathrm{III})$, $\mathrm{Fe}(\mathrm{II}), \mathrm{Cu}(\mathrm{II}), \mathrm{Zn}$ (II) ions (Arbanah et al. 2012). Marinederived Aspergillus species has the efficiency to remove the lead and copper from an aqueous solution (Gazem and Nazareth 2013). However, the ability of the mangrovesderived Trichoderma on bio remediation is not recognized. Hence, the present work was tested the effect of the mangrove-derived Trichoderma/Hypocrea on removal of metals in the artificial sewage wastewater. Further this work had optimized conditions for the adsorption process using the center composite design of response surface methodology for the effective removal of the heavy metals in the sewage followed by studies on the adsorption kinetics of heavy metal removal by the fungal biomass as adsorbent. The present work carried out during the year of 2011 and 2012 at Center of Advanced study in Marine Biology, Annamalai University, India.

\section{Materials and methods}

Selection of the potential strain for lead and iron removal

Twelve isolates of Trichoderma (Hypocrea) species $T$. asperellum (TSK1), T. arundinaceum (TSK2), T. brevicompactum (TSK3), T. ghanense (TSK4), T. aggressivum (TSK5), $H$. viridescens (TSK6), T. hamatum (TSK7), $H$. lixii (TSK8), T. atroviride (TSK9), T. koningii (TSK10), $H$. estonica (SKS1) and H. rufa strain (SKS2) isolated from mangrove sediment were used in this study. All the Trichoderma isolates were inoculated on potato dextrose agar (PDA) and incubated at $28{ }^{\circ} \mathrm{C}$. Conidial inoculum was prepared by transferring three plugs $(5 \mathrm{~mm}$ diam) of each isolate from the colony margin after 5 day incubation separately in artificial sewage composed of $\left(\mathrm{g} \mathrm{L}^{-1}\right)$ ammonium chloride (0.4), sodium nitrite $(0.01)$, urea $(0.1)$, potassium dihydrogen phosphate $(0.1)$, potassium chloride (0.5), ferric chloride (0.3), cupric chloride (0.02), zinc sulfate $(0.05)$, lead nitrate $(0.01)$, potassium dichromate (0.01) and manganous chloride (0.05) in 1-L erlenmeyer flask and incubated at rotary shaker $(180 \mathrm{rpm})$ at $30{ }^{\circ} \mathrm{C}$ for 1 week (Gomathi et al. 2012). After this, the fungal biomass was harvested and filtered through the Whatman No. 1 filter paper. The level of metals was quantified in the biomass using an inductively coupled plasma system ICP-Optical Emission Spectrophotometer (Optima 2100DV) against known standards. Among the tested strains, H. lixii was found efficient in removal of lead and iron. It was used for the further bioadsorption, optimization, kinetic and equilibrium studies.

\section{Preparation of dried Hypocrea lixii biomass}

One milliliter of concentrated aqueous conidia inoculum of H. lixii (about $10^{12}$ spores $\mathrm{mL}^{-1}$ ) was inoculated in the $500 \mathrm{~mL}$ of potato dextrose broth medium (50\% seawater) in 1-L erlenmeyer flask and incubated at $28 \pm 2{ }^{\circ} \mathrm{C}$. After 12 days of incubation, the fungal biomass was harvested, boiled in $0.5 \mathrm{~N} \mathrm{NaOH}$ solution for $15 \mathrm{~min}$ and then washed repeatedly 0020 with deionized water till neutrality. After washing, the biomass was dried at $60{ }^{\circ} \mathrm{C}$ for $24 \mathrm{~h}$ and powdered in a mortar and pestle. The dried biomass was stored in a desiccator and used for further experiments.

Preparation of the adsorbate stock solution

All the chemicals [analytical reagents (AR) grade] were purchased form HI media Mumbai, India, and used in the experiments

A stock solution $\left(1000 \mathrm{mg} \mathrm{L}^{-1}\right)$ of lead and iron was prepared by dissolving $150.8 \mathrm{mg} \mathrm{L}^{-1}$ of analytical grade lead(II) nitrate $\left[\mathrm{Pb}\left(\mathrm{NO}_{3}\right)_{2}\right]$ and iron(II) sulfate $\left(\mathrm{FeSO}_{4}\right)$ in $500 \mathrm{~mL}$ of de-ionized, double distilled water. Required initial concentration of lead and iron standards was prepared by appropriate dilution of the above stocks of lead and iron standard solution. The desired $\mathrm{pH}$ was maintained by the addition of $1 \mathrm{M} \mathrm{HCl}$ or $\mathrm{NaOH}$ at the beginning of the experiments according the experimental design of response surface methodology. The change in the working volume due to the addition of $\mathrm{HCl}$ or $\mathrm{NaOH}$ was negligible. Fresh dilutions were used for each experiment.

\section{Biosorption experiments}

In the adsorption experiments, the effects of experimental factors on metal removal were assessed. The factors tested 
were temperature $\left(10-50{ }^{\circ} \mathrm{C}\right)$, biosorbent dosage $(0.2-$ $\left.1 \mathrm{~g} \mathrm{~L}^{-1}\right)$ and adsorption processing time (0-60 min) and agitation (100-500 rpm) on lead and iron adsorption. The biosorption experiments were performed in $250-\mathrm{mL}$ Erlenmeyer flasks according to statistical experimental design, derived from center composite model of response surface methodology. In all the experiments, at the end of the desired minute of contact time, the residual lead and iron concentration in the solution was estimated after filtering the samples through Whatman No. 1 filter paper. The filtrate was analyzed for residual lead and iron concentrations using an inductively coupled plasma system ICPOptical Emission Spectrophotometer (Optima 2100DV)— and quantified against known standards. Without biosorbent was run simultaneously as control. The kinetic and isotherm method was carried out followed by optimization condition of lead and iron removal as detected using response surface methodology of central composite design (CCD). The coded values of the process parameters on lead and iron removal were calculated by following Eqs. 1 and 2 , respectively.

$Y 1$ Lead removal $(\%)=\beta_{0}+\Sigma_{i} \beta_{i} X_{i}+\Sigma_{i} \beta_{i i} X_{i}^{2}$

$$
+\Sigma_{i j} \beta_{i j} X_{i} X_{j}
$$

$Y 2$ Iron removal $(\%)=\beta_{0}+\Sigma_{i} \beta_{i} X_{i}+\Sigma_{i} \beta_{i i} X_{i}^{2}$

$$
+\Sigma_{i j} \beta_{i j} X_{i} X_{j}
$$

where $Y i$ is the predicted response, $X_{i}$ and $X_{j}$ are independent variables, $\beta_{0}$ is the offset term, $\beta_{i}$ is the $i$ th linear coefficient, $\beta_{i i}$ is the $i$ th quadratic coefficient and $\beta_{i j}$ is the $i j$ th interaction coefficient. However, in this study, the independent variables were coded as $X_{1}, X_{2}, X_{3}$ and $X_{4}$. Thus, the second-order polynomial equation can be presented in Eq. 3:

$Y 1$ and $Y 2=\beta_{0}+\beta_{1} X_{1}+\beta_{2} X_{2}+\beta_{3} X_{3}+\beta_{4} X_{4}+\beta_{11} X_{1}^{2}$

$$
\begin{aligned}
& +\beta_{22} X_{2}^{2}+\beta_{33} X_{3}^{2}+\beta_{44} X_{4}^{2}+\beta_{12} X_{1} X_{2} \\
& +\beta_{13} X_{1} X_{3}+\beta_{14} X_{1} X_{4}+\beta_{23} X_{2} X_{3}+\beta_{24} X_{2} X_{4} \\
& +\beta_{34} X_{3} X_{4}
\end{aligned}
$$

A statistical program package Design Expert 8.0.6 was used for regression analysis of the data obtained and to estimate the coefficient of the regression equation. The equations were validated by the statistical tests called the ANOVA analysis.

\section{Kinetic studies}

Batch experiments were conducted for optimum adsorbent dosage, equilibrium time. The amount of adsorbed lead and iron was calculated using Eq. (4) by the difference of initial and residuals amounts of lead and iron in solution divided by the mass of adsorbent. The removal efficiency, $R_{e}$ (determined as the lead and iron removal percentage relative to initial concentration), using Eq. (5) of the system, was calculated as:

$q_{\mathrm{e}}=\left[\left(C_{0}-C_{\mathrm{e}}\right) \times V\right] / M$

$R_{\mathrm{e}}=\left[\left(C_{0}-C_{\mathrm{e}}\right) / C_{0}\right] \times 100$

where $q_{\mathrm{e}}\left(\mathrm{mg} \mathrm{g}^{-1}\right)$ is the amount of the lead and iron adsorbed per unit mass of $H$. lixii biomass. $C_{0}$ and $C_{\mathrm{e}}$ are the initial and equilibrium (or at any time) concentration $(\mathrm{mg} / \mathrm{L})$, respectively, $V$ is the volume of lead and iron solution in liter of experimental solution and $M$ is the fungal mass $(\mathrm{g})$.

Batch isotherms studies

After determining the optimum $\mathrm{pH}$, temperature and equilibrium time, isotherm studies were conducted by varying the biomass of $H$. lixii. Representative masses $(0.2$, 0.4, 0.6, 0.8 and $1 \mathrm{~g} \mathrm{~L}^{-1}$ ) of $H$. lixii were added into $0.6 \mathrm{~g} \mathrm{~L}^{-1}$ of solution contain $150.8 \mathrm{mg} \mathrm{L}^{-1}$ and $123.56 \mathrm{mg} \mathrm{L}^{-1}$ of lead and iron, respectively, for $60 \mathrm{~min}$, and the equilibrium time for the lead and iron was assessed individually. The initial $\mathrm{pH}$ of the lead and iron solutions was adjusted to an optimum value of $\mathrm{pH} 9$ with $0.1 \mathrm{M}$ $\mathrm{NaOH}$ or $\mathrm{HCl}$.

\section{Results and discussion}

Selection of the potential mangrove-derived

Trichoderma for removal of heavy metals

Trichoderma strains were screened for selecting most potent strain for metal removal from artificial sewage. Of the 12 strains tested, $H$. lixii TSK8 showed a high accumulation of lead (68.5) and iron $(64.9 \%)$ than other Trichoderma biomass.

\section{Analysis of model fitness}

The quadratic model fitness and acceptance was assessed based on the statistical significance and lack of fit on the response of lead and iron removal. Student's $t$ test and analysis of variance fitted to second-order polynomial equation. The probability values of $<0.05$ indicate that the variables are statistically significant. The model was highly significant ( $F$ 2.48; $P$ 0.045; $d f$-14), and the lack of the fit was not significant $(F 0.541 ; P 0.80 ; d f 10)$ for the response of lead and iron removal ( 3 and 4 ), and hence, the quadratic model was valid for the present study. A low value of standard error (0.43) between the measured and model data 
Table 1 Analysis of variance (ANOVA) table for response surface methodology of main effects and interacting effects of parameters in quadratic model for the response of lead removal

\begin{tabular}{|c|c|c|c|c|c|}
\hline Source & Sum of squares & $d f$ & Mean square & $F$ value & $P$ value prob $>F$ \\
\hline Model & $25,518.94$ & 14 & $1,822.781$ & 2.485817 & $0.0455^{*}$ \\
\hline$X_{1}$-temperature $\left({ }^{\circ} \mathrm{C}\right)$ & $1,368.815$ & 1 & $1,368.815$ & 1.866721 & $0.1920^{\mathrm{NS}}$ \\
\hline$X_{2}$ 一agitation (rpm) & 4.567538 & 1 & 4.567538 & 0.006229 & $0.9381^{\mathrm{NS}}$ \\
\hline$X_{3}$-adsorbent dose $\left(\mathrm{g} \mathrm{L}^{-1}\right)$ & 100.737 & 1 & 100.737 & 0.13738 & $0.7161^{\mathrm{NS}}$ \\
\hline$X_{4}$-incubation time (min) & 983.6801 & 1 & 983.6801 & 1.341494 & $0.2649^{\mathrm{NS}}$ \\
\hline$X_{1} X_{2}$ & 0.770006 & 1 & 0.770006 & 0.00105 & $0.9746^{\mathrm{NS}}$ \\
\hline$X_{1} X_{3}$ & 0.012656 & 1 & 0.012656 & $1.73 \mathrm{E}-05$ & $0.9967^{\mathrm{NS}}$ \\
\hline$X_{1} X_{4}$ & 7.493906 & 1 & 7.493906 & 0.01022 & $0.9208^{\mathrm{NS}}$ \\
\hline$X_{2} X_{3}$ & 5.028806 & 1 & 5.028806 & 0.006858 & $0.9351^{\mathrm{NS}}$ \\
\hline$X_{2} X_{4}$ & 7.439256 & 1 & 7.439256 & 0.010145 & $0.9211^{\mathrm{NS}}$ \\
\hline$X_{3} X_{4}$ & 70.26631 & 1 & 70.26631 & 0.095826 & $0.7612^{\mathrm{NS}}$ \\
\hline$X_{1}^{2}$ & 3461.471 & 1 & $3,461.471$ & 4.720581 & $0.0462^{*}$ \\
\hline$X_{2}^{2}$ & $13,134.13$ & 1 & $13,134.13$ & 17.91166 & $0.0007^{* * *}$ \\
\hline$X_{3}^{2}$ & $11,952.55$ & 1 & $11,952.55$ & 16.30028 & $0.0011^{* * *}$ \\
\hline$X_{4}^{2}$ & $1,343.08$ & 1 & $1,343.08$ & 1.831625 & $0.1960^{\mathrm{NS}}$ \\
\hline Residual & $10,999.09$ & 15 & 733.2724 & & \\
\hline Lack of fit & $5,720.002$ & 10 & 572.0002 & 0.541761 & $0.8085^{\mathrm{NS}}$ \\
\hline Pure error & $5,279.084$ & 5 & $1,055.817$ & & \\
\hline Cor total & $36,518.02$ & 29 & & & \\
\hline
\end{tabular}

Statistically significant $* * * P<0.0001, * P<0.05, N S$ nonsignificant

showed that the equation adequately represented actual relationship between lead and iron removal and significant variables. High value of $R^{2}(0.69)$ was very close to the predicted value of $R^{2}$, and it indicated a high dependence and correlation between the observed and the predicted values of response. The parameters were then fitted into second-order polynomial equation as follows:

Lead removal $(\%)=80.70+7.55 X_{1}-0.44 X_{2}+2.05 X_{3}$

$$
\begin{aligned}
& -6.40 X_{4}+0.22 X_{1} X_{2}-0.02 X_{1} X_{3} \\
& -0.68 X_{1} X_{4}+0.56 X_{2} X_{3}-2.10 X_{2} X_{4} \\
& -2.10 X_{3} X_{4}-11.23 X^{2}-21.88 X^{2} \\
& -20.88 X^{3}-7.00 X^{4}
\end{aligned}
$$

Iron removal $(\%)=74.90+7.55 X_{1}-0.44 X_{2}+2.05 X_{3}$

$$
\begin{aligned}
& -6.40 X_{4}+0.22 X_{1} X_{2}-0.02 X_{1} X_{3} \\
& -0.68 X_{1} X_{4}+0.56 X_{2} X_{3}-2.10 X_{2} X_{4} \\
& -2.10 X_{3} X_{4}-11.23 X^{2}-21.88 X^{2} \\
& -20.88 X^{3}-7.00 X^{4}
\end{aligned}
$$

where $X_{1}$-temperature $\left({ }^{\circ} \mathrm{C}\right), X_{2}$-agitation (rpm), $X_{3}$ adsorbent dosage $\left(\mathrm{mg} \mathrm{L}^{-1}\right)$ and $X_{4}$-incubation time (min).

Validation of the model was also carried out by plotting standard error in response as a function of a pair of factors. Further fitness of the model was detected by fitting the predicted and experimental values of metal removal, and the normal probability plot was assessed (Supplementary Fig 1). The shape of the standard error plot was not only found to fit on the design points but also the polynomial showed low and flat errors, exhibiting circular contours and symmetrical shape around the centroid, representing best condition. The optimization and individual and interactions of factor effects were assessed one by one for lead and iron removal using dried biomass of Hypocrea lixii.

Individual and interaction effects of the factors on lead removal by Hypocrea lixii

The analysis of variance for effects of the individual and interactions is reported in Table 1 . The effects of $\mathrm{A}^{2}, \mathrm{~B}^{2}$, $\mathrm{C}^{2}$ and $\mathrm{D}^{2}$ showed the significance on the lead removal, and other individual and interaction effects were not significant. Optimization of conditions for the augmented lead removal was assessed using perturbation plot (Supplementary Fig 2). The maximum of $94.4 \%$ of $\mathrm{Pb}$ was removed from the aqueous solution under the optimal conditions: temperature of $46{ }^{\circ} \mathrm{C}$, agitation of $195 \mathrm{rpm}$ and adsorbent dosage of $0.63 \mathrm{~g} . \mathrm{l}^{-1}$ at $47 \mathrm{~min}$ of incubation time. 
Table 2 Analysis of variance (ANOVA) table for response surface methodology of main effects and interacting effects of parameters in quadratic model for the response of iron removal

\begin{tabular}{|c|c|c|c|c|c|}
\hline Source & Sum of squares & $d f$ & Mean square & $F$ value & $P$ value Prob $>F$ \\
\hline Model & $25,518.94$ & 14 & $1,822.781$ & 2.485817 & $0.0455^{*}$ \\
\hline$X_{1}$-temperature $\left({ }^{\circ} \mathrm{C}\right)$ & $1,368.815$ & 1 & $1,368.815$ & 1.866721 & $0.1920^{\mathrm{NS}}$ \\
\hline$X_{2}$ 一agitation (rpm) & 4.567538 & 1 & 4.567538 & 0.006229 & $0.009381^{* *}$ \\
\hline$X_{3}$-adsorbent dose $\left(\mathrm{g} \mathrm{L}^{-1}\right)$ & 100.737 & 1 & 100.737 & 0.13738 & $0.007161^{* *}$ \\
\hline$X_{4}$-incubation time (min) & 983.6801 & 1 & 983.6801 & 1.341494 & $0.2649^{\mathrm{NS}}$ \\
\hline$X_{1} X_{2}$ & 0.770006 & 1 & 0.770006 & 0.00105 & $0.9746^{\mathrm{NS}}$ \\
\hline$X_{1} X_{3}$ & 0.012656 & 1 & 0.012656 & $1.73 \mathrm{E}-05$ & $0.9967^{\mathrm{NS}}$ \\
\hline$X_{1} X_{4}$ & 7.493906 & 1 & 7.493906 & 0.01022 & $0.9208^{\mathrm{NS}}$ \\
\hline$X_{2} X_{3}$ & 5.028806 & 1 & 5.028806 & 0.006858 & $0.9351^{\mathrm{NS}}$ \\
\hline$X_{2} X_{4}$ & 7.439256 & 1 & 7.439256 & 0.010145 & $0.9211^{\mathrm{NS}}$ \\
\hline$X_{3} X_{4}$ & 70.26631 & 1 & 70.26631 & 0.095826 & $0.7612^{\mathrm{NS}}$ \\
\hline$X_{1}^{2}$ & 3461.471 & 1 & $3,461.471$ & 4.720581 & $0.0462^{*}$ \\
\hline$X_{2}^{2}$ & $13,134.13$ & 1 & $13,134.13$ & 17.91166 & $0.0007^{* * *}$ \\
\hline$X_{3}^{2}$ & $11,952.55$ & 1 & $11,952.55$ & 16.30028 & $0.0011^{* *}$ \\
\hline$X_{4}^{2}$ & 1343.08 & 1 & $1,343.08$ & 1.831625 & $0.1960^{\mathrm{NS}}$ \\
\hline Residual & $10,999.09$ & 15 & 733.2724 & & \\
\hline Lack of fit & $5,720.002$ & 10 & 572.0002 & 0.541761 & $0.8085^{\mathrm{NS}}$ \\
\hline Pure error & $5,279.084$ & 5 & $1,055.817$ & & \\
\hline Cor total & $36,518.02$ & 29 & & & \\
\hline
\end{tabular}

Statistically significant $* * * P<0.0001, * P<0.05, N S$ nonsignificant

Individual and interaction effects of the factors on iron removal by Hypocrea lixii

The analysis of variance for effects of the individual and interactions is reported in Table 2. The effects of $\mathrm{B}, \mathrm{C}, \mathrm{A}^{2}$, $\mathrm{B}^{2}$ and $\mathrm{C}^{2}$ showed the significance on the iron removal, and other individual and interaction effects were not significant. Optimization of conditions for the augmented iron removal was assessed using perturbation plot (Supplementary Fig 3). A maximum of $88.4 \%$ of iron was removed from the aqueous solution under the optimal conditions: temperature of $54{ }^{\circ} \mathrm{C}$, agitation of $170 \mathrm{rpm}$ and adsorbent dosage of $0.52 \mathrm{~g} \mathrm{~L}^{-1}$ at $34 \mathrm{~min}$ of incubation time.

Kinetic and isotherm experiments

Isotherm and kinetic evaluations were tested using firstand second-order kinetic equation models and adsorption isotherm. Statistically optimized factors were used in kinetic studies. Optimized conditions for efficient lead removal are known $\mathrm{Pb}$ concentration of $150.8 \mathrm{mg} \mathrm{L}^{-1}$ and adsorbent concentration of $0.63 \mathrm{~g} \mathrm{~L}^{-1}$ at $46^{\circ} \mathrm{C}$ and agitation of $195 \mathrm{rpm}$ for $120 \mathrm{~min}$ of processing time. The determination of the residual $\mathrm{Pb}$ and iron concentration in aqueous solution was tested at definite intervals of $30 \mathrm{~min}$ over a period of $120 \mathrm{~min}$. The case of iron removal was also tested with the known concentration of $150.8 \mathrm{mg} \mathrm{L}^{-1}$ and absorbent concentration of $0.52 \mathrm{~g} \mathrm{~L}^{-1}$ at $54{ }^{\circ} \mathrm{C}$, agitation of $170 \mathrm{rpm}$ for $120 \mathrm{~min}$ of processing time.

\section{Adsorption kinetics}

The kinetics of removal of lead and iron was explicitly explained in the literature using first-order and secondorder kinetic models. The adsorption of iron and lead was analyzed using Lagergren rate equation. The first-order Lagergren model is Eq. (8) (Gasser et al. 2007)

$\mathrm{d} q_{t} / \mathrm{Dt}=k_{1}\left(q_{\mathrm{e}}-q_{t}\right)$

where $q_{t}$ is the amount of lead and iron adsorbed on the adsorbent at time $t(\mathrm{~min})$ and $k_{1}(1 / \mathrm{min})$ is the rate constant of first-order adsorption. The incorporated form of the above equation with the state line conditions $t=0$ to $>0$ ( $q=0$ to $>0$ ) and then rearranged to obtain the following time dependence function Eq. (9),

$\log \left(q_{\mathrm{e}}-q_{t}\right)=\log q_{\mathrm{e}}-\left(k_{1} / 2.303\right) t$

where $q_{\mathrm{e}}$ is the amount of lead and iron was adsorbed at equilibrium. The $q_{\mathrm{e}}$ and rate constant for the removal of the lead and iron removal $\left(k_{1}\right)$ were calculated from the slope of the plots of $\log \left(q_{\mathrm{e}}-q_{\mathrm{t}}\right)$ versus time ( $t$ ) (Fig. 1), 


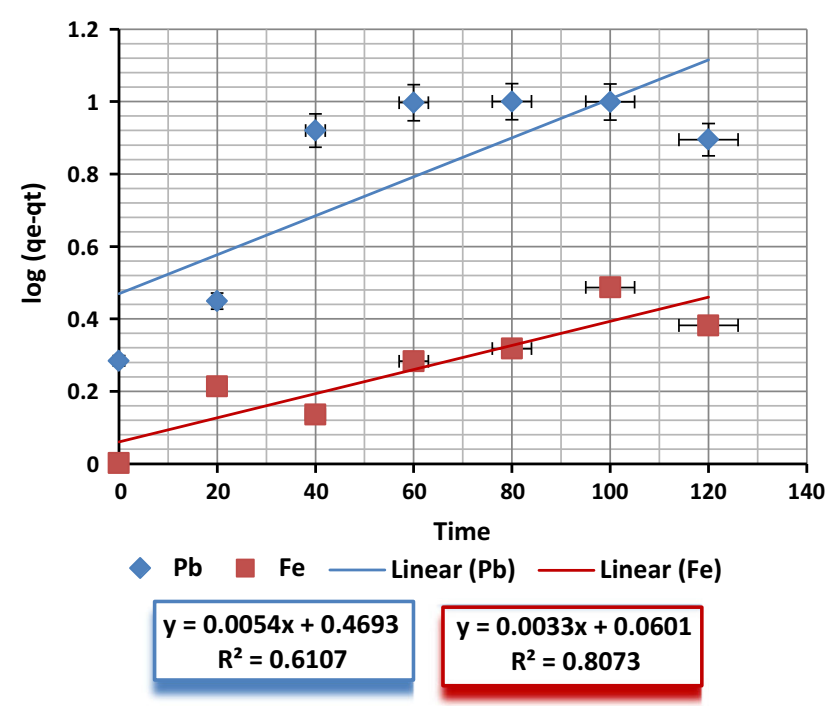

Fig. 1 Kinetic analysis of lead and iron adsorption by Hypocrea lixii in linear plots of pseudo first-order rate equations

respectively. It was found that the calculated $q_{\mathrm{e}}$ value did not agree with the experimental $q_{\mathrm{e}}$ values. The secondorder kinetic model is expressed as Eq. (10)

$\left(\mathrm{d} q_{t} / D t\right)=k_{1}\left(q_{\mathrm{e}}^{2}-q_{t}^{2}\right)$

where $k_{2}$ is the rate constant of second-order adsorption. The integrated form of Eq. (11) with the boundary condition $t=0$ to $>0(q=0$ to $>0)$ is

$t / q_{t}=\left[\left(1 / k_{2} q_{\mathrm{e}}^{2}\right)+(1 / t)\right] t$

Equation (11) can be rearranged and linearized as,

$h=k_{2} q_{\mathrm{e}}^{2}$

The plot $t / q_{t}$ versus time ( $t$ ) (2) showed the straight line. The second-order kinetic values of $q_{\mathrm{e}}$ and $k_{2}$ were calculated from the slope and intercept of the plots $t / q_{t}$ versus $t$ (Fig. 2). Table 3 depicts the computed results obtained from first- and second-order kinetic model. The calculated $q_{\mathrm{e}}$ values agreed well with the experimental $q_{\mathrm{e}}$ values for second-order kinetics model better than the first-order kinetics model for adsorption capacity of adsorbent. These results indicated that the adsorption system belonged to the both kinetic model of first- and second-order kinetics.

\section{Adsorption isotherm}

The equilibrium adsorption isotherm is of importance in the design of adsorption systems (Wang et al. 2005). The Langmuir isotherm was used in this study. The Langmuir
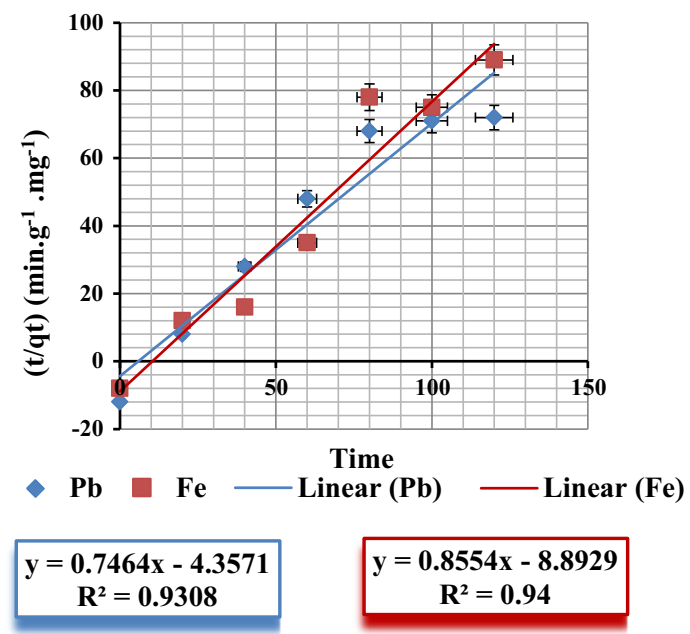

Fig. 2 Kinetic analysis of lead and iron adsorption by Hypocrea lixii in linear plots of pseudo-second-order rate equations

Table 3 Lagergren constants, pseudo-second-order rate constants for lead and iron by Hypocrea lixii

\begin{tabular}{|c|c|c|c|c|c|c|}
\hline & \multicolumn{6}{|c|}{ Lagergren constants } \\
\hline & $q_{\exp }$ & $K_{1} \times 10^{-3}$ & $R^{2}$ & $Q_{\mathrm{e}}$ & $K_{2} \times 10^{-3}$ & $R^{2}$ \\
\hline \multicolumn{7}{|c|}{ Lead $\left(\mathrm{mg} \mathrm{L}^{-1}\right)$} \\
\hline 150.8 & 149.32 & 0.005 & 0.61 & 90 & 1.68 & 1 \\
\hline \multicolumn{7}{|c|}{ Iron $\left(\mathrm{mg} \mathrm{L}^{-1}\right)$} \\
\hline 150.8 & $1,148.5$ & 0.003 & 0.80 & 92 & 1.68 & 1 \\
\hline
\end{tabular}

adsorption isotherms assumes that adsorption takes place at specific homogeneous sites within the adsorbent and has found successful applications to many sorption process of monolayer adsorption. The Langmuir adsorption isotherm can be written as Eq. (13).

$q_{e}=\left(q_{m} b c_{e}\right) /\left(1+b c_{e}\right)$

The Langmuir parameters were obtained by fitting the experimental data to the linearized equation derived from Eq. (13):

$C_{\mathrm{e}} / q_{\mathrm{e}}=\left(1 / b q_{\mathrm{m}}\right)+\left(C_{\mathrm{e}} / q_{\mathrm{m}}\right)$

$1 / \mathrm{q}_{\mathrm{e}}=\left[\left(1 / \mathrm{b} q_{\mathrm{m}}\right) \times\left(1 / q_{\mathrm{m}}\right)+\left(1 / q_{\mathrm{m}}\right)\right]$

where $q_{\mathrm{e}}$ is the adsorbent amount ( $\mathrm{mg} \mathrm{g}^{-1}$ ) of the lead and iron, $C_{\mathrm{e}}$ is the equilibrium concentration of the lead and iron in solution $\left(\mathrm{mg} \mathrm{l}^{-1}\right), q_{\mathrm{m}}$ is the monolayer adsorption capacity $\left(\mathrm{mg} \mathrm{g}^{-1}\right)$ and $b$ is the constant related to the free energy of adsorption $\left(\mathrm{L} \mathrm{mg}^{-1}\right)$. Based on Eqs. (9) and (14), the isotherms were fitted to the adsorption data obtained. 
Table 4 Langmuir isotherm constant for adsorption of lead and iron removal by Hypocrea lixii

\begin{tabular}{lcc}
\hline Langmuir isotherm parameters & $C_{\mathrm{e}} / q_{\mathrm{e}}$ & $1 / q_{\mathrm{e}}$ \\
\hline Lead removal $\left(\mathrm{mg} \mathrm{L}^{-1}\right)$ & & \\
$q_{\mathrm{m}}\left(\mathrm{mg} \mathrm{g}^{-1}\right)$ & 60 & 60 \\
$b\left(\mathrm{~L} \mathrm{mg}^{-1}\right)$ & 0.64 & 0.51 \\
$R^{2}$ & 1 & 1.13 \\
Iron removal (mg L & \\
$q_{\mathrm{m}}\left(\mathrm{mg} \mathrm{g}^{-1}\right)$ & & 45 \\
$\mathrm{~b}\left(\mathrm{~L} \mathrm{mg}^{-1}\right)$ & 45 & 0.36 \\
$\mathrm{R}^{2}$ & 0.42 & 1.42 \\
\hline
\end{tabular}
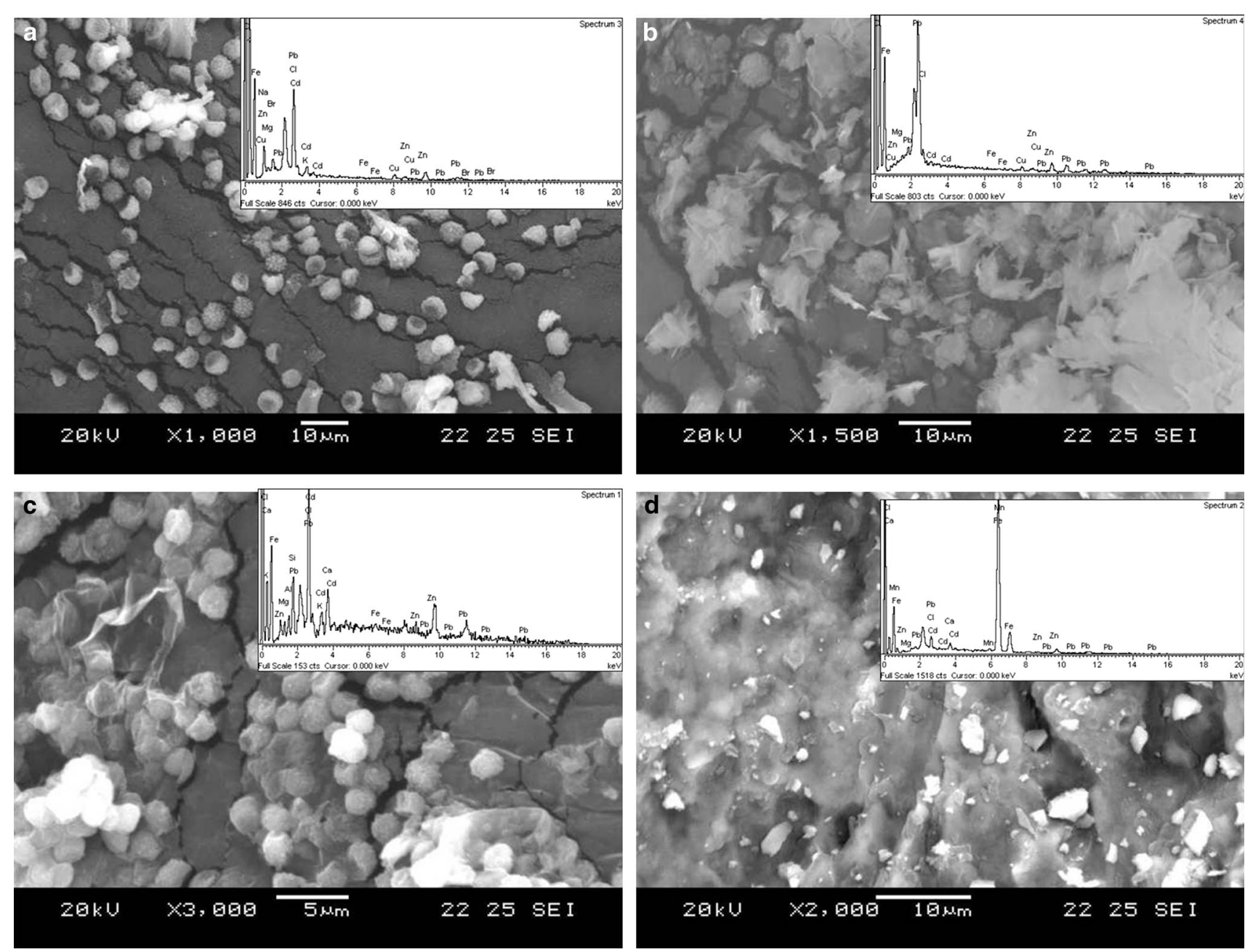

Fig. 3 SEM photograph and EDS for the surface of the adsorbent before and after adsorption process, a Hypocrea lixii dried biomass before

adsorption of $\mathrm{pb}, \mathbf{b}$ the dried biomass after adsorption of $\mathrm{pb}, \mathbf{c}$ the biomass before adsorption of $\mathrm{Fe}, \mathbf{d}$ the dried biomass after adsorption of Fe
The Langmuir adsorption exponents for Eqs. (14) and (15), the $q_{\mathrm{m}}$ and $b$ were determined from the linear plots of $C_{\mathrm{e}} / q_{\mathrm{e}}$ versus $C_{\mathrm{e}}$ and $1 / q_{\mathrm{e}}$ versus $1 / C_{\mathrm{e}}$, and correlation coefficients for these isotherms were calculated, as shown in Table 4. The values of Langmuir constant were calculated from the slopes and intercepts of the plots. The magnitude of Langmuir constant $b$ was small $\left(0.64 \mathrm{~L} \mathrm{mg}^{-1}\right)$ in lead, and the adsorption capacity qm was determined as $49.2 \mathrm{mg} \mathrm{g}^{-1}$ for lead removal. These adsorption capacity was higher than that obtained from some research work, 4.06 by $M$. rouxii (Yan and Veraraghavan 2001). Similarly, the present absorption capacity was less than some filamentous fungus and yeasts isolated from terrestrial region (Lo et al. 1999). 
However, Akhtara et al. (2007) have reported that 32-60\% uranium is removed from aqueous solution by $T$. harzianum biomass after 15 min of incubation time, but in the present study bioadsorbent showed the adequate adsorption of $94.4 \%$ of $\mathrm{Pb}$ and $88.4 \%$ of iron from the aqueous solution with in the incubation period $34 \mathrm{~min}$ and adsorbent dosage of $0.52 \mathrm{~g} \mathrm{~L}^{-1}$ for lead. In the case of the iron removal, $q_{\mathrm{m}}$ was calculated as $51.3 \mathrm{mg} \mathrm{g}^{-1}$ and $b$ was $0.42 \mathrm{~L} \mathrm{mg}^{-1}$ as assessed from the present kinetic model.

Scanning electron microscopic studies

The adsorbent surface structure is presented in Fig. 3a-d. It shows the SEM images of dried H. lixii biomass before and after lead and iron adsorption process. Figure $3 \mathrm{a}$, c exhibits the distinct fungal spores with more space between them for the adsorption process. Figure $3 \mathrm{~b}$ shows the fungal biomass after adsorption of lead, and Fig. $3 \mathrm{~d}$ exhibits the fungal biomass after adsorption of iron. After biosorption of the metals, spores are not visible and the spaces between the spores are filled by metals. The biosorption of metals was also confirmed by $\mathrm{X}$-ray energy-dispersive spectrometer.

This work tested the efficiency of fungal biomass on metal removal under varied range of factors. For which, central composite design (CCD) was employed to optimize the biosorption process due to its suitability (Schiewer and Volesky 1995; Montgomery 2001; Tang and $\mathrm{Xu}$ 2002; Goksungur et al. 2005; Amini et al. 2008). Based on this methodology, the present study achieved the maximum $\mathrm{Pb}$ removal of $94.4 \%$ under the optimal conditions: temperature of $46{ }^{\circ} \mathrm{C}$, agitation of $195 \mathrm{rpm}$, adsorbent dosage of $0.63 \mathrm{~g}^{-1}$ at $47 \mathrm{~min}$ of incubation time. Similarly, the work attained the maximum iron removal of $88.4 \%$ under the optimal conditions: temperature of $54{ }^{\circ} \mathrm{C}$, agitation of $170 \mathrm{rpm}$, adsorbent dosage of $0.52 \mathrm{~g} \mathrm{l}^{-1}$ at $34 \mathrm{~min}$ of incubation time. Thus, the fungal strains of Hypocrea were found capable of removing lead and iron, depending on the culture conditions. Similarly, many researchers have reported that fungi such as Trichoderma, Aspergillus, Paecilomyces lilacinus and the arbuscular mycorrhizal fungi are able to remove metals in contaminated soils (Adams et al. 2007; Lebeau et al. 2008; Tsekova et al. 2010; Sharma and Adholeya 2011).

Scanning electron microscopic observations revealed the maximum adsorption and significant changes in the surface of adsorbent (Figs. 2b, c), which is due to participation of specific functional groups on the adsorbent surface (Mohan and Karthikeyan 1997; Wang et al. 2009). The kinetics of the present study revealed that the adsorbent (H. lixii biomass) showed the significant adsorbing capacity of the metals. This result is in accordance with previous workers (Kehe et al. 2010; Joshi et al. 2011).

\section{Conclusion}

Trichoderma species of terrestrial origin have been used in bioremediation process for pollution removal because the fungus is able to produce secondary metabolites which can denature and detoxify the pollutants. Similarly, Trichoderma strain SP2F1 isolated from terrestrial site removes chromium (Gadd 1992; Adeline et al. 2009). The marine sponge-derived Trichoderma sp., Gc1 is efficient to degrade the pesticide (DDT) 1, 1-dichloro-2,2-bis-(4chlorophenyl) ethane (Ortega et al. 2011) and to reduce the contamination of 1-(4-methoxyphenyl) ethanone (Lenilson et al. 2012). Chromium-resistant strains of marine $T$. viride are efficient in the chromium removal from the industrial effluent (El-Kassas and El-Taher 2009). The maximum adsorption capacity of the $49.2 \mathrm{mg} \mathrm{g}^{-1}$ for lead and $51.3 \mathrm{mg} \mathrm{g}^{-1}$ iron by the H. lixii was higher than the copper adsorption capacity of $19.0 \mathrm{mg} \mathrm{g}^{-1}$ by $H$. lixii isolated from the terrestrial region (Marcia et al. 2013). This comparison proved the significance of mangroves-derived H. lixii toward the terrestrial microbes. The present study concluded that dried biomass of the mangrove-derived marine strain of $H$. lixii TSK8 was the potent biosorbent for efficient bioremediation process.

Acknowledgments The authors are thankful to the authorities of Annamalai University, India.

\section{References}

Adams P, De-Leij FA, Lynch JM (2007) Trichoderma harzianum Rifai 1295-22 mediates growth promotion of Crack willow Salix fragilis saplings in both clean and metal-contaminated soil. Microb Ecol 54:306-313

Akhtara Kalsoom, Waheed Akhtarb M, Khalidc AM (2007) Removal and recovery of uranium from aqueous solutions by Trichoderma harzianum. Water Res 41:1366-1378

Allen LH (2002) Supplement: Forging effective strategies to combat iron deficiency. J Nutr Am Soc Nutr Sci 132:813S-819S

Amini M, Younesi H, Bahramifar N, Lorestani AAZ, Ghorbani F, Daneshi A, Sharifzadeh M (2008) Application of response surface methodology for optimization of lead biosorption in an aqueous solution by Aspergillus niger. J Hazard Mater 154:694-702

Annibale D, Sermanni GG, Federic F, Petruccioli M (2006) Olivemill waster waters: a promising substrate of microbial lipase production. Bioresour Technol 15:1828-1833

Arbanah M, Miradatul Najwa MR, Ku Halim KH (2012) Biosorption of $\mathrm{Cr}(\mathrm{III}), \mathrm{Fe}(\mathrm{II}), \mathrm{Cu}(\mathrm{II}), \mathrm{Zn}$ (II) Ions from Liquid Laboratory Chemical Waste by Pleurotus ostreatus. Int $\mathrm{J}$ Biotechnol Wellness Ind 1:152-162 
Ayyappan R, Sophia AC, Swaminathan K, Sandhya S (2003) Removal of $\mathrm{Pb}$ (II) from aqueous solution using carbon derived from agricultural wastes. Process Biochem 40:1293-1299

Brasil JL, Ev RR, Milcharek CD, Martins LC, Pavan FA, Santos Dias SLP, Dupont J, Norena CPZ, Lima EC (2006) Statistical design of experiments as a tool for optimizing the batch conditions to $\mathrm{Cr}(\mathrm{VI})$ biosorption on Araucaria angustifolia wastes. J Hazard Mater 133:143-153

Canizares-Villanueva RO, Travieso L (1991) Inmovilización de microalgaspara el tratamiento de residuales. Informe CONACyT. Proyecto 8.07/91Programa Cuba-Mexico

Cavaco SA, Fernandes S, Quina MM, Ferreira LM (2007) Removal of chromium from electroplating industry effluents by ion exchange resins. J Hazard Mater 144:634-638

Dae WC, Young HK (2005) Chromium (VI) removal in a semi continues process of hallow fiber membrane with organic extractants. Kor J Chem Eng 22:894-898

Dean JG, Bosqui FL, Lanouette KH (1972) Removing heavy metals from wastewater. Environ Sci Technol 6:518-524

Deng H, Honghong Y, Xiaolong T, Ping N, Qiongfen Y (2011) Adsorption of $\mathrm{CO}_{2}$ and $\mathrm{N}_{2}$ on Coal-based activated carbon. Adv Mater Res 204-210:1250-1253

El-Kassas HY, El-Taher EM (2009) Optimization of batch process parameters by response surface methodology for mycoremediation of chrome-VI by a chromium resistant strain of marine Trichoderma Viride. Am-Eurasian J Agric Environ Sci 5(5):676-681

Gadd GM (1992) Heavy metals pollutants: environmental and biotechnological aspects. Encycl Microbiol 2:22-43

Gasser B, Sauer M, Maurer M, Stadlmayr G, Mattanovich D (2007) Transcriptomics-based identification of novel factors enhancing heterologous protein secretion in yeasts. Appl Environ Microbiol 73:6499-6507

Gazem MAH, Nazareth S (2013) Sorption of lead and copper from an aqueous phase system by marine-derived Aspergillus species. Ann Microbiol 63:503-551

Goksungur Y, Uren S, Guvenc U (2005) Biosorption of cadmium and lead ions by ethanol treated waste baker's yeast biomass. Bioresour Technol 96(1):103-109

Gomathi V, Saravanakumar K, Kathiresan K (2012) Biosorption of chromium by mangrove-derived Aplanochytrium sp. Afr J Biotechnol 11(95):16177-16186

Joshi PK, Anand S, Sonu M, Raman K, Namita S (2011) Bioremediation of heavy metals in liquid media through fungi isolated from contaminated sources. Indian J Microbiol 51(4):482-487

Kehe F, Lixing L, Lili F, Tong L, Jie C (2010) Accumulation of copper in Trichoderma reesei transformants, constructed with the modified Agrobacterium tumefaciens-mediated transformation technique. Biotechnol Lett 32:1815-1820

Kurt K, Apaydin O, Gonullu MT (2007) Reduction of COD in wastewater from an organized tannery industrial region by Electro-Fenton process. J Hazard Mater 143:33-40

Lebeau T, Braud A, Jezequel K (2008) Performance of bioaugmentation-assisted phytoextraction applied to metal contaminated soils: a review. Environ Pollut 153:497-522

Lenilson CR, Hercules VF, Rodrigo FL, Lara DS, Andre LMP (2012) Stereoselective bioreduction of 1-(4-Methoxyphenyl) ethanone by whole cells of marine-derived fungi. Mar Biotechnol 14:358-362

Lo W, Chua H, Lam KH, Bi SP (1999) A comparative investigation on the biosorption of lead by filamentous fungal biomass. Chemosphere 39(15):2723-2736
Marcia RS, Luiz FL, Rômulo AA, Cláudio A, Nascimento BC (2013) Biosynthesis and uptake of copper nanoparticles by dead biomass of Hypocrea lixii isolated from the metal mine in the Brazilian Amazon region. Plos One 8(11):80519

Mavrov V, Stamenov S, Todorova E, Chmiel H, Erwe T (2006) Removal of nickel ions from wastewater by $\mathrm{Mg}(\mathrm{OH})_{2} / \mathrm{MgO}$ nanostructures embedded in $\mathrm{Al}_{2} \mathrm{O}_{3}$ membranes. J Alloys Compd. 426:281-285

Mohan VS, Karthikeyan J (1997) Removal of lignin and tannin aqueous solution by adsorption onto activated charcoal. Environ Poll 1-2:183-197

Montgomery DC (2001) Design and analysis of experiments, 5th edn. Wiley, New York

Ortega NO, Nitschke M, Mouad AM, Landgraf MD, Rezende MOO, Seleghim MHR, Sette LD, Porto ALM (2011) Isolation of Brazilian marine fungi capable of growing on DDD Pesticide. Biodegradation 22:43-50

Schiewer S, Volesky B (1995) Modelling of the proton-metal ion exchange in biosorption. Environ Sci Technol 29:3049-3058

Sharma S, Adholeya A (2011) Detoxification and accumulation of chromium from tannery effluent and spent chrome effluent by Paecilomyces lilacinus fungi. Int Biodeterior Biodegrad. 65:309-317

Silbergeld EK, Waalkes M, Rice JM (2000) Lead as a carcinogen: experimental evidence and mechanism of action. Am J Ind Med 38:316-325

Smedley PL, Zhan M, Zhang G, Luo Z (2003) Mobilisation of arsenic and other trace elements in fluviolacustrine aquifers of the Huhhot Basin, Inner Mongolia. Appl Geochem 18(9):1453-1477

Srivastava AK, Naqvi AH, Sinha AK, Vishwakarma SR, Roy GC (2004) Genotype and environment interaction in Antheraea mylitta Drury and its implications. Pers Cytol Genet 11:219-224

Tang LC, Xu K (2002) A unified approach for dual response surface optimization. J Qual Technol 34:437-447

Tastan BE, Ertugrul S, Donmez G (2010) Effective bioremoval of reactive dye and heavy metals by Aspergillus versicolor. Bioresour Technol 101:870-876

Ting ASY, Choong CC (2009) Bioaccumulation and biosorption efficacy of Trichoderma isolate SP2F1 in removing copper $(\mathrm{Cu}(\mathrm{II}))$ from aqueous solutions. World J Microbiol Biotechnol 25:1431-1437

Travieso L, Pellon A, Benitez F, Sanchez E, Borja R, O'Farrill N, Weiland P (2002) BIOALGA reactor: preliminary studies for heavy metals removal. Biochem Eng J 12:87-91

Tsekova K, Todorova D, Ganeva S (2010) Removal of heavy metals from industrial wastewater by free and immobilized cells of Aspergillus niger. Int Biodeterior Biodegradation 64:447-451

Wang S, Boyjoo Y, Choueib A (2005) A comparative study of dye removal using fly ash treated by different methods. Chemosphere 60:1401-1407

Wang Y, Sakamoto Y, Kamiya Y (2009) Remediation of actual groundwater polluted with nitrate by the catalytic reduction over copper-palladium supported on active carbon. Applied Catalysis A. $361: 123-129$

Xiao X, Luo SL, Zeng GM, Wan WZY, Chen L (2010) Biosorption of cadmium by endophytic fungus (EF) Microsphaeropsis $\mathrm{sp}$ LSE10 isolated from cadmium hyper accumulator Solanum nigrum L. Bioresour Technol 101:1668-1674

Yan G, Veraraghavan T (2001) Heavy metal removal in a biosorption column by immobilsed Mucar rouxii biomass. Bioresour Technol 78:243-249 
Yetilmezsoy K, Demirel S, Vanderbei RJ (2009) Response surface modeling of $\mathrm{Pb}(\mathrm{II})$ removal from aqueous solution by Pistacia vera L.: Box-Behnken experimental design. J Hazard Mater $171: 551-562$
Zhang GS, Qu JH, Liu HJ, Liu RP, Wu RC (2007) Preparation and evaluation of a novel Fe-Mn binary oxide adsorbent for elective arsenite removal. Water Res 41:1921-1928 